\title{
Karateristik Fisik Bunga Cengkeh (Syzygium aromaticum)
}

\section{(Physical characteristics of Clove (Syzygium aromaticum))}

\author{
Miftahul Jannah ${ }^{1 *}$, Junaedi Muhidong ${ }^{1)}$ dan Mursalim ${ }^{1)}$ \\ 1) Program Studi Keteknikan Pertanian Universitas Hasanuddin \\ ${ }^{*}$ Email korespondensi: miftahul.jannah21@gmail.com
}

\begin{abstract}
Clove (Syzygium aromaticum), belongs to the Myrtaceae family and is one of Indonesia's native spice plants originating from the Maluku Islands. Clove post-harvest handling at the farm level is still done manually, one of which is the separation of flowers from the stems that are still using their hands. Flowers and clove stems need to be separated because they have different prices and qualities. The purpose of this study was to determine the attachment of cloves to their stems and physical characteristics (dimensions, weight and moisture content) of clove flowers in the varieties of Zanzibar, $\mathrm{Si}$-Putih and Si-Kotok. Adhesiveness is intended as the force needed to release the clove flower from the stem so that it can be a reference and basic reference in the design of the clove flower separator from the stem or other processing equipment. This study used samples of clove flower varieties of Zanzibar, Si-Putih and Si-Kotok based on the color of the flower (level of maturity). The results of this study indicate that the adhesiveness of the clove Si-Kotok variety is $0.22 \mathrm{~kg}$, the Zanzibar variety is $0.17 \mathrm{~kg}$ and the $\mathrm{Si}$-Putih variety is $0.15 \mathrm{~kg}$. In terms of color, the adhesiveness of red clove flowers is $0.22 \mathrm{~kg}$, red green is $0.17 \mathrm{~kg}$ and green is $0.16 \mathrm{~kg}$. The adhesiveness of cloves does not have a consistent correlation with the parameters of the physical properties of cloves.
\end{abstract}

Keywords: Cloves, Stickiness, Physical Characteristics

\begin{abstract}
ABSTRAK
Cengkeh (Syzygium aromaticum), termasuk dalam famili Myrtaceae dan merupakan salah satu tanaman rempah asli Indonesia yang berasal dari Kepulauan Maluku. Penanganan pasca panen cengkeh di tingkat petani masih dilakukan dengan cara manual, salah satunya pemisahan bunga dari tangkainya yang masih menggunakan tangan. Bunga dan tangkai cengkeh perlu dipisahkan karena mempunyai harga dan mutu yang berbeda. Tujuan penelitian ini adalah untuk mengetahui daya lekat bunga cengkeh terhadap tangkainya dan karateristik fisik (dimensi, berat dan kadar air) bunga cengkeh pada varietas Zanzibar, Si-Putih dan Si-Kotok. Daya lekat dimaksudkan sebagai gaya yang dibutuhkan untuk melepaskan bunga cengkeh dari tangkainya agar dapat menjadi acuan dan referensi dasar dalam perancangan alat pemisah bunga cengkeh dari tangkainya atau alat processing lainnya. Penelitian ini menggunakan sampel bunga cengkeh varietas Zanzibar, Si-Putih dan Si-Kotok berdasarkan warna bunga (tingkat kematangan). Hasil penelitian ini menunjukkan bahwa daya lekat yang diperoleh bunga cengkeh varietas Si-Kotok sebesar $0.22 \mathrm{~kg}$, varietas Zanzibar sebesar $0.17 \mathrm{~kg}$ dan varietas Si-Putih sebesar $0.15 \mathrm{~kg}$. Dari sisi warna, daya lekat bunga cengkeh warna merah sebesar $0.22 \mathrm{~kg}$, warna merah hijau sebesar $0.17 \mathrm{~kg}$ dan warna hijau sebesar $0.16 \mathrm{~kg}$. Daya lekat bunga cengkeh tidak memiliki korelasi yang konsisten dengan parameter sifat fisik bunga cengkeh.
\end{abstract}

Kata Kunci: Cengkeh, Daya Lekat, Karateristik Fisik 


\section{PENDAHULUAN}

\section{Latar Belakang}

Tanaman cengkeh dikenal sebagai tanaman rempah yang digunakan sebagai obat tradisional maupun modern. Cengkeh juga banyak digunakan dalam industri sebagai pembuatan rokok kretek, bahan pembuatan minyak atsiri, bahan baku pembuatan vanillin dan bahan parfum.

Untuk mendapatkan hasil yang bermutu baik, masalah pengolahan pasca panen cengkeh juga perlu untuk diperhatikan dengan seksama. Penanganan pasca panen cengkeh ditingkat petani masih dilakukan dengan cara tradisional, salah satunya pemisahan bunga dari tangkainya yang masih menggunakan tangan sehingga membutuhkan waktu yang lama. Bunga dan tangkai cengkeh perlu dipisahkan karena mempunyai harga dan mutu yang berbeda. Dengan kondisi tersebut maka perlu dilakukan penelitian untuk mengetahui daya lekat bunga cengkeh terhadap tangkainya agar dapat menjadi acuan dan referensi dalam perancangan alat pemisah bunga cengkeh dari tangkainya atau alat processing lainnya.

\section{Tujuan dan Kegunaan}

Penelitian ini bertujuan untuk mengetahui daya lekat bunga cengkeh terhadap tangkainya dan karateristik fisik (dimensi, berat dan kadar air) bunga cengkeh pada varietas Zanzibar, SiPutih dan Si-Kotok. Daya lekat dimaksudkan sebagai gaya yang dibutuhkan untuk melepaskan bunga cengkeh dari tangkainya. Kegunaan penelitian ini adalah dapat menjadi acuan dan referensi dasar dalam perancangan alat pemisah bunga cengkeh dari tangkainya atau alat processing lainnya.

\section{METODOLOGI PENELITIAN}

\section{Alat dan Bahan}

Alat yang digunakan dalam penelitian ini adalah tekstur analizer, jangka sorong, timbangan digital, desikator, kulkas dan oven.

Bahan yang digunakan dalam penelitian ini adalah 50 tangkai bunga cengkeh varietas Zanzibar, Si-Putih dan Si-Kotok dari Desa
Bulutellue, Kecamatan Bulupoddo, Kabupaten Sinjai.

\section{Prosedur Penelitian}

1. Menyiapkan cengkeh yang baru di panen meliputi cengkeh varietas Zanzibar, SiPutih, Si-Kotok masing-masing 50 tangkai.

2. Memilih sampel pada bunga cengkeh varietas Zanzibar, Si-Putih, Si-Kotok masing-masing 20 tangkai pada kondisi yang baik.

3. Setiap tangkai cengkeh dipilih satu bunga cengkeh yang memiliki warna hijau, merah hijau dan merah pada masing-masing varietas cengkeh.

4. Menyiapkan wadah yang telah diberi label berupa nama masing-masing varietas cengkeh berdasarkan warnanya (tingkat kematangan).

5. Meletakkan sampel di atas papan pengalas pada alat tekstur analizer. Setiap tangkai yang telah dipilih warna hijau, merah hijau dan merah akan diukur daya lekat bunganya pada masing-masing varietas bunga cengkeh. Jarak antara tangkai bunga cengkeh dengan jarum tekstur analizer sekirar $\pm 3 \mathrm{~mm}$.

6. Mengoperasikan alat tersebut kemudian melihat hasil grafiknya pada layarkomputer.

7. Menimbang bunga cengkeh dari semua varietas berdasarkan warnanya (tingkat kematangan).

8. Mengukur dimensi yang meliputi panjang, diameter-atas dan diameter-bawah bunga cengkeh kemudian meletakkan ke dalam wadah pada masing-masing varietas berdasarkan warnanya (tingkat kematangan).

9. Memasukkan ke dalam oven (pada suhu $105^{\circ} \mathrm{C}$ selama 72 jam) untuk mendapatkan berat kering sebagai basis perhitungan kadar air. 


\section{Diagram Alir Penelitian}

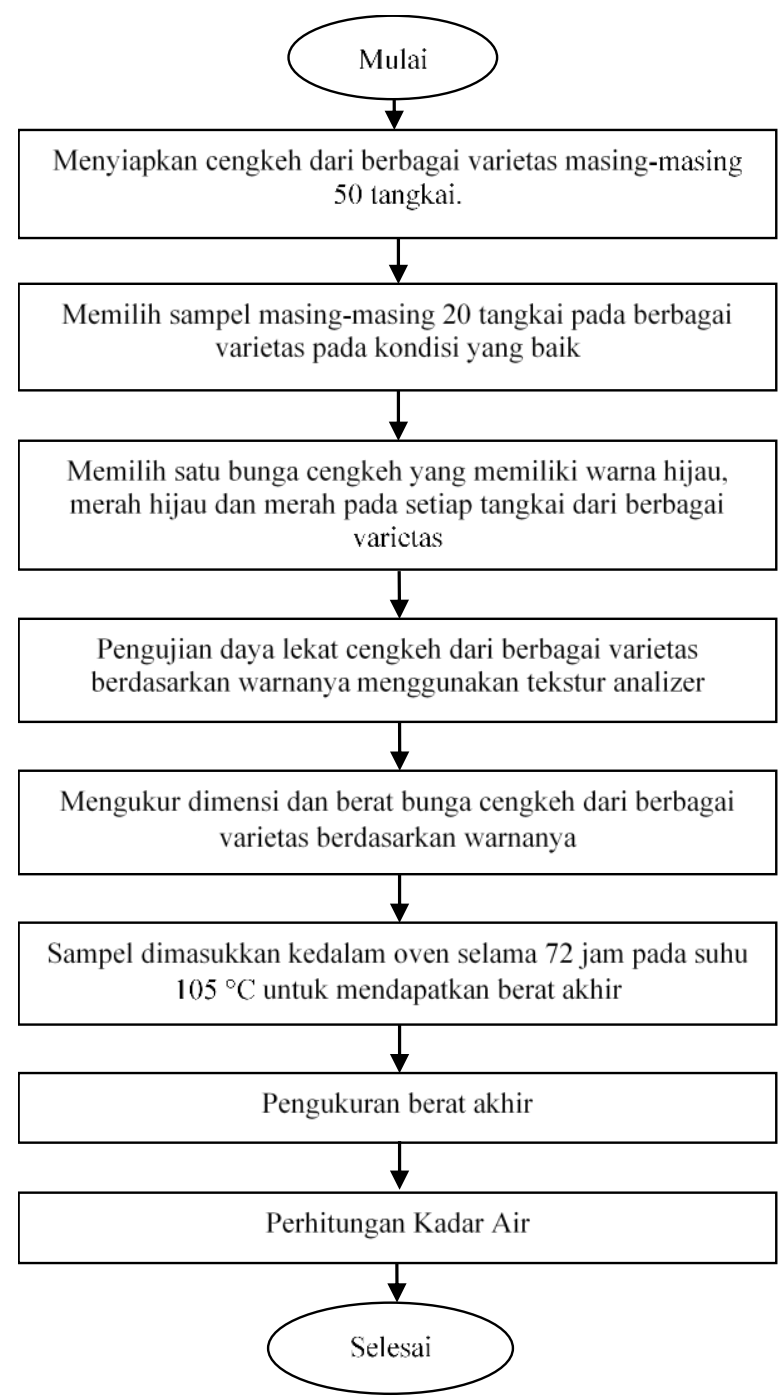

Gambar 1. Diagram Alir Penelitian.

\section{HASIL DAN PEMBAHASAN}

\section{Pengujian Daya Lekat Bunga Cengkeh Varietas Zanzibar, Si-Putih dan Si-Kotok}

Hasil pengujian daya lekat bunga cengkeh varietas Zanzibar, Si-Putih dan Si-Kotok berdasarkan tingkat kematangannya disajikan pada Gambar 3 di bawah ini:

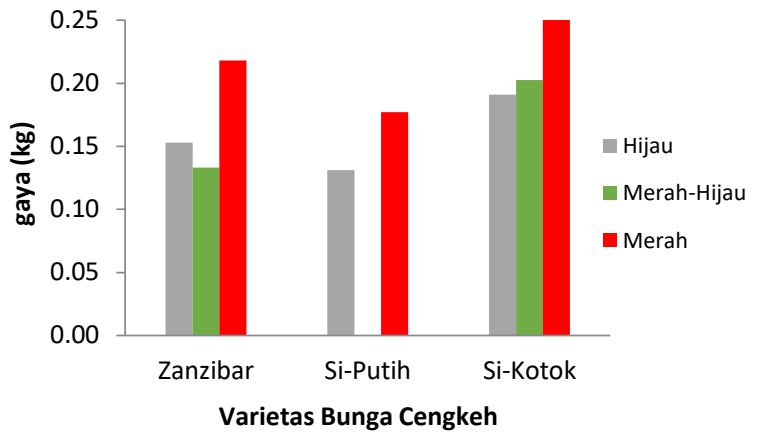

Gambar 3. Daya Lekat Bunga Cengkeh Varietas Zanzibar, Si-Putih dan Si-Kotok.

Gambar 3 menunjukkan bahwa daya lekat bunga cengkeh pada tangkai di pengaruhi oleh varietas cengkeh. Hal ini dapat dilihat bahwa varietas Si-Kotok memiliki daya lekat yang lebih besar dibandingkan varietas Zanzibar dan Si-Putih. Demikian juga daya lekat bunga cengkeh varietas Zanzibar lebih kuat daripada bunga varietas Si-Putih. Rata-rata daya lekat Si-Kotok, Zanzibar dan Si-Putih masing-masing sebesar $0.22 \mathrm{~kg}, 0.17 \mathrm{~kg}$ dan $0.15 \mathrm{~kg}$.

Gambar 3 di atas juga menunjukkan bahwa dari semua varietas, warna bunga cengkeh (menandakan tingkat kematangan bunga cengkeh) berpengaruh terhadap daya lekat. Warna merah memiliki daya lekat yang lebih besar dibandingkan dengan bunga cengkeh berwarna hijau dan merah hijau. Ratarata daya lekat bunga cengkeh warna hijau, merah hijau dan merah adalah $0.16 \mathrm{~kg}, 0.17 \mathrm{~kg}$ dan $0.22 \mathrm{~kg}$.

Pengukuran Diameter-atas dan Diameterbawah pada Bunga Cengkeh Varietas Zanzibar, Si-Putih dan Si-Kotok

Hasil pengukuran dimensi diameter-atas pada bunga cengkeh varietas Zanzibar, SiPutih dan Si-Kotok berdasarkan tingkat kematangannya disajikan pada Gambar 4 di bawah ini: 


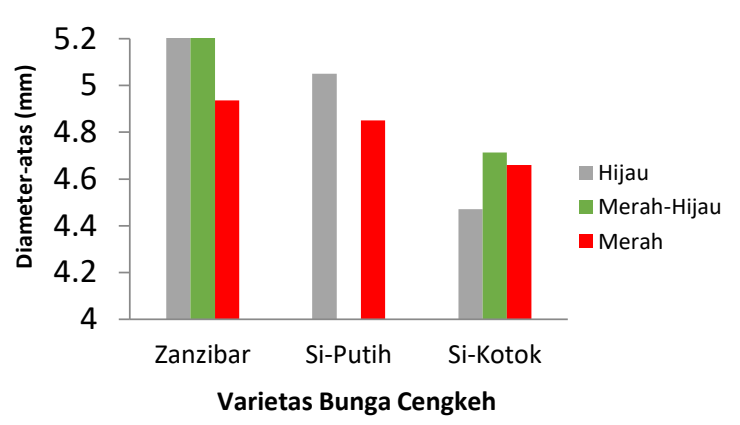

Gambar 4. Diameter-atas (mm) pada Bunga Cengkeh Varietas Zanzibar, Si-Putih dan SiKotok

Dapat dilihat pada Gambar 4 bahwa hasil pengukuran diameter-atas pada bunga cengkeh di pengaruhi oleh varietas bunga cengkeh. Hal tersebut dapat dilihat bahwa bunga cengkeh varietas Zanzibar memiliki diameter-atas (mm) yang lebih besar yaitu sebesar $5.15 \mathrm{~mm}$ dibandingkan Si-Putih dan Si-Kotok yang masing-masing sebesar $4.95 \mathrm{~mm}$ dan $4.61 \mathrm{~mm}$. Demikian juga varietas Si-Kotok justru lebih kecil dibandingkan dengan varietas Si-Putih.

Pada Gambar 4 dapat dilihat bahwa warna bunga cengkeh (menandakan tingkat kematangan bunga cengkeh) dari semua varietas juga mempengaruhi besar kecilnya diameter-atas pada bunga tersebut. Bunga cengkeh warna merah hijau memiliki ukuran diameter-atas lebih besar jika dibandingkan dengan bunga cengkeh warna merah dan warna hijau. Rata-rata hasil pengukuran diameter-atas bunga cengkeh warna merah hijau, merah dan hijau masing-masing sebesar $4.98 \mathrm{~mm}, 4.82 \mathrm{~mm}$ dan $4.45 \mathrm{~mm}$.

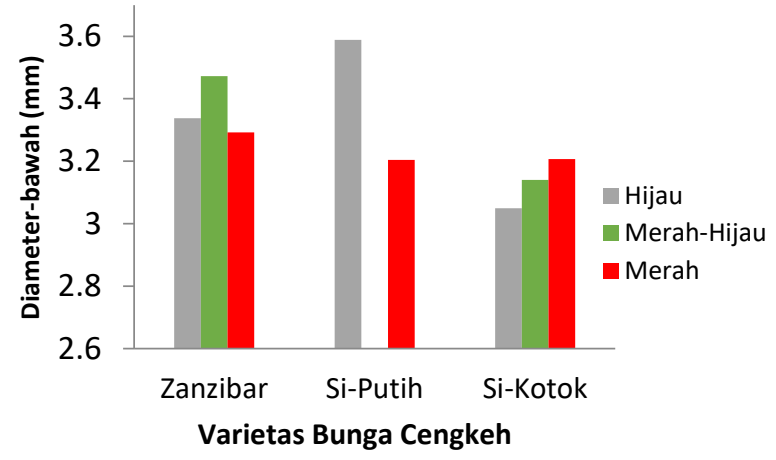

Gambar 5. Diameter-bawah (mm) pada Bunga Cengkeh Varietas Zanzibar, Si-Putih dan SiKotok
Dapat dilihat pada Gambar 5 bahwa hasil pengukuran diameter-bawah pada bunga cengkeh tersebut juga dipengaruhi oleh varietas bunga cengkeh. Hal tersebut dapat dilihat bahwa bunga cengkeh varietas Si-Putih memiliki diameter-bawah yang lebih besar yaitu sebesar $3.40 \mathrm{~mm}$ dibandingkan varietas Zanzibar dan Si-Kotok yang masing-masing sebesar $3.37 \mathrm{~mm}$ dan $3.13 \mathrm{~mm}$.

Gambar 5 juga dapat dilihat bahwa warna bunga cengkeh (menandakan tingkat kematangan bunga cengkeh) dari semua varietas juga mempengaruhi besar kecilnya diameter-bawah pada bunga tersebut. Bunga cengkeh warna hijau memiliki ukuran diameter-atas lebih besar jika dibandingkan dengan warna merah hijau dan warna merah pada bunga cengkeh tersebut. Rata-rata hasil pengukuran diameter-atas bunga cengkeh warna hijau, merah hijau dan merah masingmasing sebesar $3.33 \mathrm{~mm}, 3.31 \mathrm{~mm}$ dan 3.24 mm.

\section{Pengukuran Panjang pada Bunga Cengkeh Varietas Zanzibar, Si-Putih dan Si-Kotok}

Hasil pengukuran panjang bunga cengkeh varietas Zanzibar, Si-Putih dan Si-Kotok berdasarkan tingkat kematangannya disajikan pada Gambar 6 berikut:

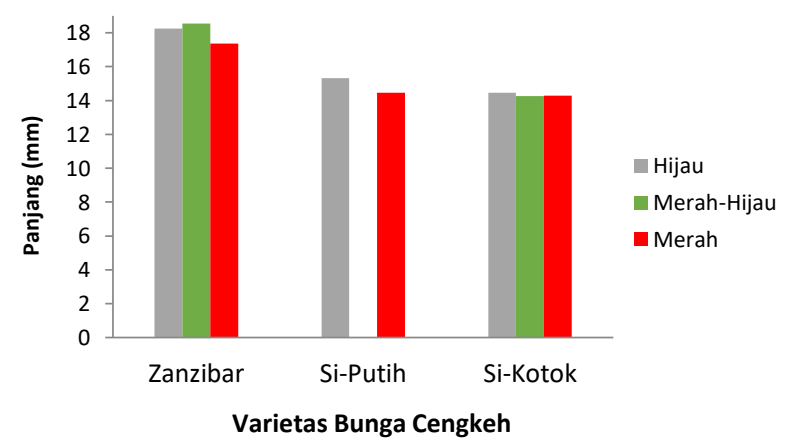

Gambar 6. Panjang (mm) pada Bunga Cengkeh Varietas Zanzibar, Si-Putih dan Si-Kotok

Gambar 6 menunjukkan hasil pengukuran panjang pada bunga cengkeh tersebut juga di pengaruhi oleh varietas cengkeh tersebut. Hal tersebut dapat dilihat bahwa bunga cengkeh varietas Zanzibar memiliki panjang yang lebih besar jika dibandingkan dengan varietas $\mathrm{Si}$ Putih dan Si-Kotok. Selain itu, varietas Si- 
Putih juga lebih besar dibandingkan varietas Si-Kotok. Rata-rata hasil pengukuran panjang pada bunga cengkeh varietas Zanzibar, SiPutih dan Si-Kotok masing-masing $18.05 \mathrm{~mm}$, $14.88 \mathrm{~mm}$ dan $14.34 \mathrm{~mm}$.

Pada Gambar 6 juga dapat dilihat bahwa dari semua varietas cengkeh, panjang bunga cengkeh warna merah hijau $(16.40 \mathrm{~mm})$ lebih besar jika dibandingkan dengan panjang bunga cengkeh warna hijau $(16.01 \mathrm{~mm})$ dan bunga cengkeh warna merah $(15.37 \mathrm{~mm})$.

Berat pada Bunga Cengkeh Varietas Zanzibar, Si-Putih dan Si-Kotok

Hasil pengamatan terhadap perilaku berat bunga cengkeh varietas Zanzibar, Si-Putih dan Si-Kotok berdasarkan tingkat kematangannya disajikan pada Gambar 7 dan 8 berikut :

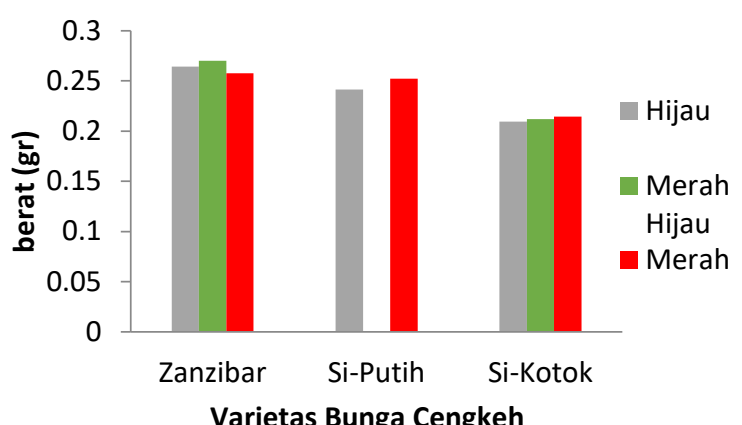

Gambar 7. Berat (gr) pada Bunga Cengkeh Varietas Zanzibar, Si-Putih dan Si-Kotok

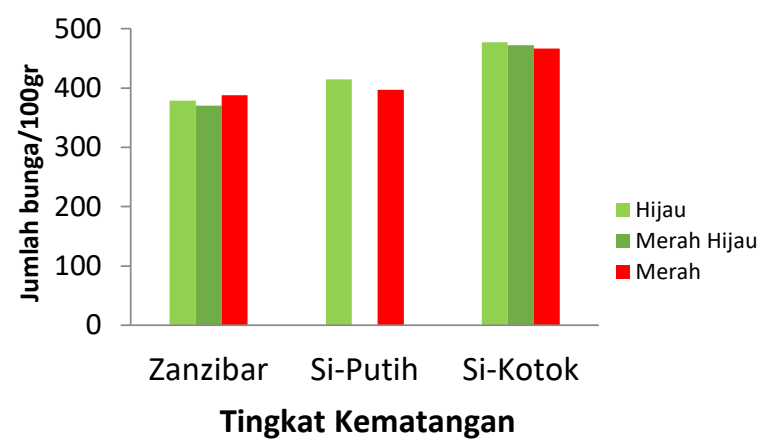

Gambar 8. Jumlah Bunga Cengkeh Per 100 Gram

Gambar 7 menunjukkan varietas cengkeh juga mempengaruhi berat bunga cengkeh tersebut. Hal ini dapat dilihat dimana bunga cengkeh varietas Zanzibar memiliki berat yang lebih besar dibandingkan varietas Si-Putih dan Si-Kotok. Demikian juga dengan berat bunga cengkeh varietas Si-Putih lebih besar jika dibandingkan dengan varietas Si-Kotok. Rata- rata berat bunga cengkeh varietas Zanzibar, SiKotok dan Si-Putih masing-masing sebesar 0.264 gr, 0.247 gr dan 0.212 gr.

Gambar 7 juga dapat dilihat bahwa dari semua varietas cengkeh yang menandakan tingkat Kematangannya, berat bunga cengkeh warna merah $(0.724$ gr $)$ lebih besar dibandingkan dengan bunga cengkeh warna merah hijau (0.241 gr) dan warna hijau (0.238 gr).

Gambar 8 menunjukkan bahwa jumlah bunga cengkeh per 100 gram pada varietas Zanzibar warna hijau sebanyak 378 bunga, warna merah hijau sebanyak 370 bunga dan warna merah sebanyak 388 bunga. Pada varietas Si-Putih warna hijau sebanyak 414 bunga dan warna merah sebanyak 397. Pada varietas Si-Kotok warna hijau sebanyak 477 bunga, warna merah hijau sebanyak 472 bunga dan warna merah sebanyak 466 bunga. Semakin kecil berat bunga per 100 gram makan semakin besar jumlah bunga cengkehnya.

\section{Kadar Air pada Bunga Cengkeh Varietas Zanzibar, Si-Putih dan Si-Kotok}

Hasil pengamatan terhadap perilaku kadar air bunga cengkeh varietas Zanzibar, Si-Putih dan Si-Kotok berdasarkan tingkat kematangannya disajikan pada Gambar 9 berikut:

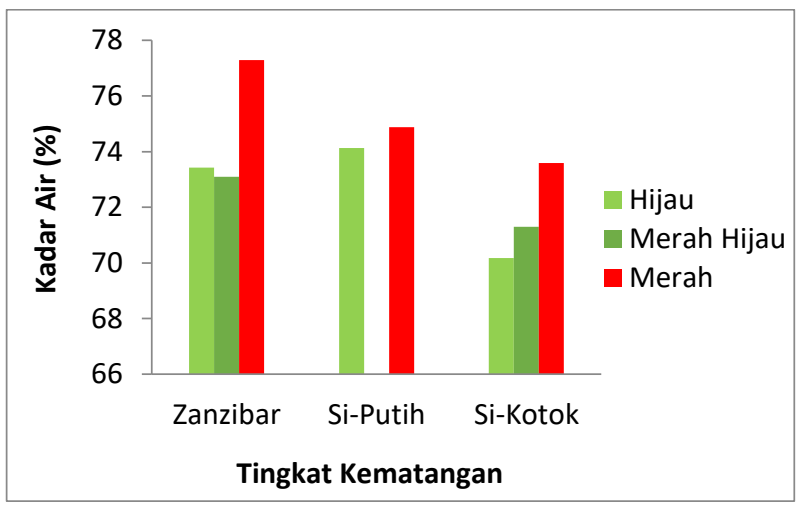

Gambar 9. Kadar air (\%) pada Bunga Cengkeh Varietas Zanzibar, Si-Putih dan Si-Kotok

Dari Gambar 9 menunjukkan bahwa kadar air juga dipengaruhi oleh varietas dari bunga cengkeh tersebut. Dapat dilihat bahwa dari ketiga varietas bunga cengkeh tersebut, 
bunga cengkeh varietas Zanzibar memiliki kadar air lebih tinggi dibandingkan bunga cengkeh varietas Si-Putih. Demikian juga dengan kadar air bunga cengkeh varietas $\mathrm{Si}$ Kotok lebih kecil jika dibandingkan dengan bunga cengkeh varietas Si-Putih. Rata-rata hasil pengukuran kadar air dari bunga cengkeh varietas Zanzibar, Si-Putih dan Si-Kotok masing-masing $74.60 \%, 74.50 \%$ dan $71.69 \%$.

Pada Gambar 9 terlihat jelas tingkat kematangan berdasarkan warna bunga cengkeh mempengaruhi kadar air. Hal ini dapat dilihat bahwa kadar air bunga cengkeh warna merah lebih tinggi yaitu sebesar $75.25 \%$ jika dibandingkan dengan warna hijau dan warna merah hijau yang kadar airnya masingmasing sebesar $72.57 \%$ dan $72.20 \%$.

\section{Korelasi Daya Lekat dan Sifat Fisik Bunga Cengkeh Varietas Zanzibar, Si-Putih dan Si-Kotok}

Hasil analisis korelasi antara dimensi (Diameter-atas, Diameter-bawah dan panjang), berat, kadar air, dan daya lekat bunga cengkeh varietas Zanzibar, Si-Putih dan Si-Kotok disajikan pada Tabel 1 berikut:

Tabel 1. Korelasi antara dimensi (diameter-atas, diameter-bawah dan panjang), berat, kadar air, dan daya lekat bunga cengkeh varietas Zanzibar, Si-Putih dan Si-Kotok

\begin{tabular}{|c|c|c|c|c|c|c|c|c|}
\hline Varietas & \begin{tabular}{|c|} 
Tingkat \\
Kemata \\
ngan
\end{tabular} & Sifat Fisik & $\begin{array}{c}\text { Daya } \\
\text { Lekat }\end{array}$ & DA & DB & Panjang & Berat & $\begin{array}{c}\text { Kadar } \\
\text { Air }\end{array}$ \\
\hline \multirow{18}{*}{ Zanzibar } & \multirow{6}{*}{ Hijau } & Daya Lekat & 1 & & & & & \\
\hline & & DA & -0.051 & 1 & & & & \\
\hline & & DB & 0.683 & -0.179 & 1 & & & \\
\hline & & Panjang & 0.136 & 0.176 & -0.121 & 1 & & \\
\hline & & Berat & -0.003 & 0.349 & -0.370 & 0.897 & 1 & \\
\hline & & Kadar Air & 0.178 & -0.478 & 0.566 & -0.505 & -0.833 & 1 \\
\hline & \multirow{6}{*}{$\begin{array}{l}\text { Merah } \\
\text { Hijau }\end{array}$} & Daya Lekat & 1 & & & & & \\
\hline & & $\mathrm{DA}$ & -0.015 & 1 & & & & \\
\hline & & DB & -0.140 & 0.043 & 1 & & & \\
\hline & & Panjang & -0.383 & 0.363 & 0.461 & 1 & & \\
\hline & & Berat & -0.086 & 0.726 & 0.317 & 0.649 & 1 & \\
\hline & & Kadar Air & -0.217 & -0.647 & -0.027 & 0.010 & -0.752 & 1 \\
\hline & \multirow{6}{*}{ Merah } & Daya Lekat & 1 & & & & & \\
\hline & & DA & -0.074 & 1 & & & & \\
\hline & & DB & 0.123 & 0.150 & 1 & & & \\
\hline & & Panjang & 0.582 & 0.316 & -0.065 & 1 & & \\
\hline & & Berat & -0.148 & 0.306 & -0.174 & 0.198 & 1 & \\
\hline & & Kadar Air & 0.370 & -0.191 & 0.151 & 0.180 & -0.928 & 1 \\
\hline \multirow{12}{*}{ Si-Putih } & \multirow{6}{*}{ Hijau } & Daya Lekat & 1 & & & & & \\
\hline & & DA & 0.524 & 1 & & & & \\
\hline & & $\mathrm{DB}$ & -0.143 & 0.216 & 1 & & & \\
\hline & & Panjang & 0.141 & 0.237 & -0.429 & 1 & & \\
\hline & & Berat & 0.200 & 0.591 & 0.029 & 0.557 & 1 & \\
\hline & & Kadar Air & -0.199 & -0.597 & -0.209 & -0.280 & -0.951 & 1 \\
\hline & \multirow{6}{*}{ Merah } & Daya Lekat & 1 & & & & & \\
\hline & & DA & -0.033 & 1 & & & & \\
\hline & & DB & 0.437 & 0.345 & 1 & & & \\
\hline & & Panjang & 0.157 & 0.111 & 0.185 & 1 & & \\
\hline & & Berat & 0.305 & 0.530 & 0.712 & 0.545 & 1 & \\
\hline & & Kadar Air & -0.253 & -0.585 & -0.724 & -0.096 & -0.881 & 1 \\
\hline
\end{tabular}


Jurnal AgriTechno. Vol. 13 (1): 34-41

https://doi.org/10.20956/at.v13i1.251

\begin{tabular}{|c|c|c|c|c|c|c|c|c|}
\hline Varietas & $\begin{array}{c}\text { Tingkat } \\
\text { Kemata } \\
\text { ngan }\end{array}$ & Sifat Fisik & $\begin{array}{c}\text { Daya } \\
\text { Lekat }\end{array}$ & DA & DB & Panjang & Berat & $\begin{array}{c}\text { Kadar } \\
\text { Air }\end{array}$ \\
\hline \multirow{18}{*}{$\begin{array}{c}\text { Si- } \\
\text { Kotok }\end{array}$} & \multirow{6}{*}{ Hijau } & Daya Lekat & 1 & & & & & \\
\hline & & DA & 0.127 & 1 & & & & \\
\hline & & DB & 0.124 & -0.178 & 1 & & & \\
\hline & & Panjang & -0.317 & 0.635 & -0.532 & 1 & & \\
\hline & & Berat & -0.311 & 0.734 & -0.358 & 0.879 & 1 & \\
\hline & & Kadar Air & 0.276 & -0.687 & 0.175 & -0.666 & --0.941 & 1 \\
\hline & \multirow{6}{*}{$\begin{array}{c}\text { Merah } \\
\text { Hijau }\end{array}$} & Daya Lekat & 1 & & & & & \\
\hline & & $\mathrm{DA}$ & 0.297 & 1 & & & & \\
\hline & & DB & 0.104 & 0.143 & 1 & & & \\
\hline & & Panjang & 0.031 & 0.463 & 0.143 & 1 & & \\
\hline & & Berat & 0.298 & 0.830 & 0.015 & 0.529 & 1 & \\
\hline & & Kadar Air & -0.303 & -0.610 & 0.074 & 0.164 & -0.747 & 1 \\
\hline & \multirow{6}{*}{ Merah } & Daya Lekat & 1 & & & & & \\
\hline & & DA & -0.102 & 1 & & & & \\
\hline & & DB & 0.520 & 0.565 & 1 & & & \\
\hline & & Panjang & 0.151 & 0.452 & 0.505 & 1 & & \\
\hline & & Berat & 0.029 & 0.502 & 0.487 & 0.773 & 1 & \\
\hline & & Kadar Air & 0.112 & -0.327 & -0.240 & -0.182 & -0.764 & 1 \\
\hline
\end{tabular}

Keterangan: $\mathrm{DA}=$ diameter-atas; $\mathrm{DB}=$ diameter-bawah

Dari Tabel 1 di atas menunjukkan bahwa daya lekat bunga cengkeh varietas Zanzibar warna hijau memiliki korelasi positif dengan diameter-bawah dengan nilai korelasi sebesar 0.683. Daya lekat bunga cengkeh warna merah hijau relatif tidak memiliki korelasi dengan parameter sifat fisik lainnya (diamater-atas, diamater-bawah, panjang, berat dan kadar air). Sedangkan daya lekat bunga cengkeh warna merah memiliki korelasi positif dengan panjang dengan nilai korelasi sebesar 0.582 .

Untuk varietas Si-Putih, daya lekat bunga cengkeh warna hijau memiliki korelasi positif dengan diameter-atas sebesar 0.524. Sedangkan daya lekat bunga cengkeh warna merah juga memiliki korelasi positif dengan diameter-bawah sebesar 0.437 .

Selain itu, Tabel 1 di atas menunjukkan bahwa daya lekat bunga cengkeh varietas $\mathrm{Si}$ Kotok warna hijau memiliki korelasi dengan diameter-atas, nilai korelasi sebesar 0.124. Daya lekat bunga cengkeh warna merah hijau memiliki korelasi dengan panjang sebesar 0.297. Sedangkan daya lekat bunga cengkeh warna merah memiliki korelasi dengan diameter-bawah dengan nilai 0.520 .
Fakta-fakta di atas menggambarkan bahwa parameter sifat fisik bunga cengkeh dari semua varietas berdasarkan warna bunganya (tingkat kematangan) tidak memiliki korelasi yang konsisten dengan daya lekatnya. Namun demikian, diameter-bawah memiliki frekuensi kejadian tertinggi dalam memberikan nilai korelasi terkuat dengan daya lekat bunga cengkeh. Ketidakkonsistensian ini kemungkinan besar di akibatkan oleh jumlah sampel yang digunakan untuk pengukuran daya lekat yang kurang memadai pada saat penelitian, hanya berkisar antara 10 sampai dengan 20 bunga cengkeh per varietas per tingkat kematangan.

\section{KESIMPULAN}

Berdasarkan hasil penelitian maka dapat ditarik kesimpulan bahwa:

1. Tingkat daya lekat bunga cengkeh diperoleh berturut-turut dari yang paling tinggi ke paling rendah adalah bunga cengkeh dari varietas Si-Kotok, kemudian Zanzibar dan terakhir Si-Putih. Dari sisi warna, bunga cengkeh warna merah 
memiliki daya lekat tertinggi dibandingkan dengan kedua warna lainnya. Namun demikian, daya lekat ini tidak memiliki korelasi yang konsisten dengan parameter sifat fisik bunga cengkeh.

2. Diameter-atas bunga cengkeh diperoleh berturut-turut dari yang paling tinggi ke paling rendah adalah Zanzibar, Si-Putih dan Si-Kotok. Sedangkan dari sisi warna, bunga cengkeh warna merah hijau memiliki diameter-atas tertinggi dibandingkan dengan warna lainnya. Untuk diameterbawah, diperoleh berturut-turut dari yang paling tinggi ke paling rendah adalah SiPutih, Zanzibar dan Si-Kotok. Sedangkan dari sisi warna, bunga cengkeh warna hijau memiliki diameter-bawah tertinggi dibandingkan dengan warna lainnya.

3. Panjang bunga cengkeh diperoleh dari yang paling tinggi ke paling rendah berturut-turut adalah varietas Zanzibar, kemudian SiPutih dan terakhir Si-Kotok sedangkan dari sisi warna, bunga cengkeh merah hijau memiliki panjang tertinggi dibandingkan dengan warna lainnya.

4. Untuk berat bunga cengkeh baik dilihat dari berat individual bunga maupun dari jumlah bunga per 100 gram bunga, varietas Zanzibar memiliki berat tertinggi dibandingkan kedua varietas lainnya sedangkan dari sisi warna, bunga cengkeh merah memiliki berat tertinggi dibandingkan dengan warna lainnya.

5. Cengkeh varietas Zanzibar memiliki kadar air tertinggi dibandingkan kedua varietas lainnya. Dari sisi warna, bunga cengkeh merah memiliki kadar air tertinggi dibandingkan dengan warna lainnya.

\section{DAFTAR PUSTAKA}

Aksi Agraris Kanisius. 1981. Petunjuk Bercocok Tanam Cengkeh. Penerbit Kanisius. Yogyakarta.

Anonim, 2014 ${ }^{\mathrm{b}}$. Tekstur Analyzer. http:// anyleite .wordpress. com/ 2013 /02 /11/tekstur-analizer/. Diakses pada tanggal 8 Januari 2014.

Kanisius. 1981. Petunjuk Bercocok Tanam Cengkeh. Penerbit Kanisius. Yogyakarta.

Muljana, Wahyu. 1982. Cara Praktis Bercocok Tanam Cengkeh. Penerbit CV. Aneka Semarang Yogyakarta.

Setyamidjaja, Djhohana M.Ed. Cengkeh. Penerbit CV. Yasaguna. Jakarta.

Lagousi, Kulla. 2002. Mengenal Tanaman Cengkeh. Telaga Zamzam. Makassar.

Winarno, F.G., 1997. Naskah Akademis Keamanan Pangan. Institut Pertanian Bogor. 